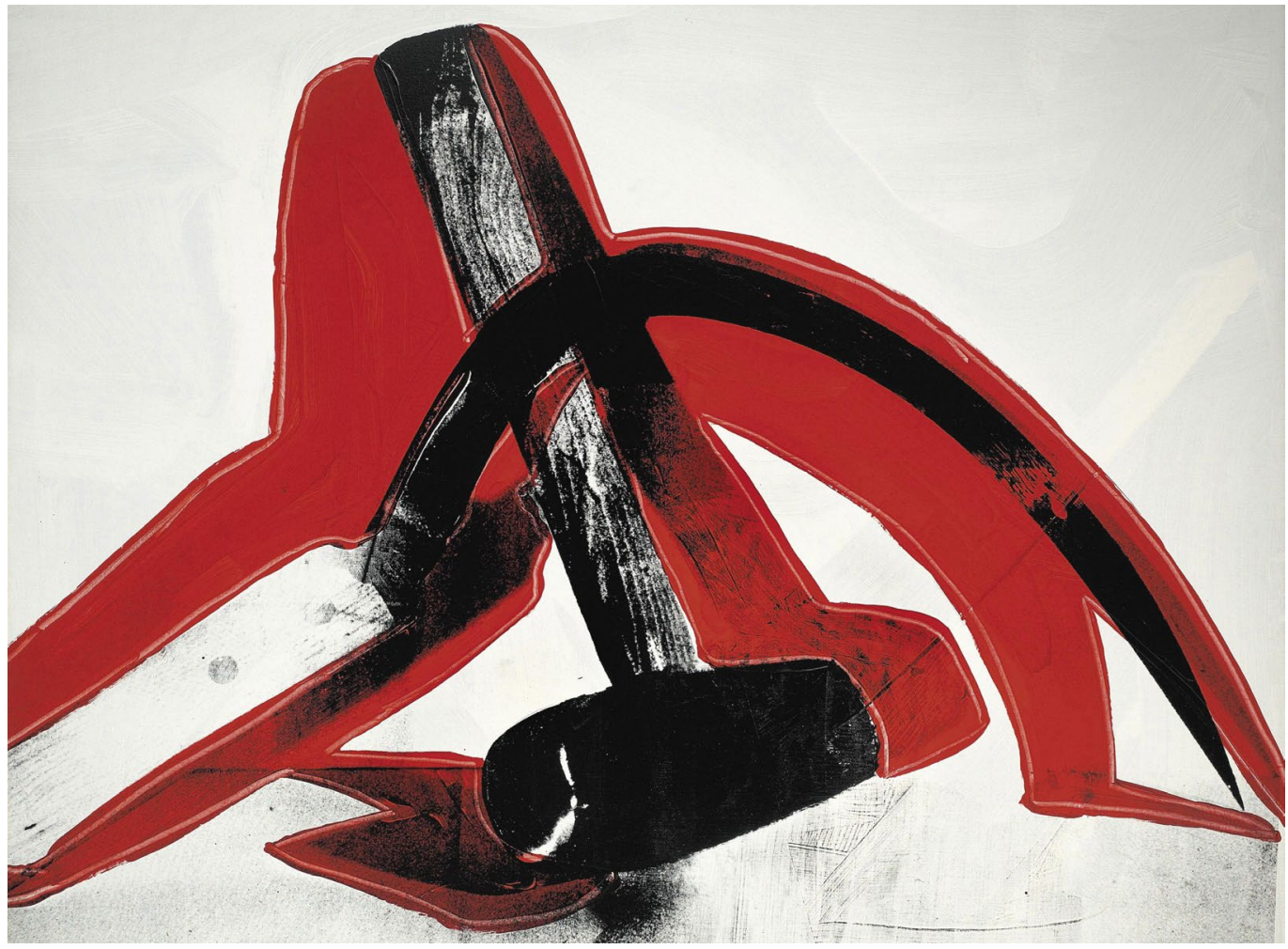

\title{
Poetry after the Future
}

\section{Christian SORACE}

In this essay, Sorace reads migrant-worker poetry alongside Marx to index the trace of a different future in the exploitation and alienation of the present. Worker poets write about lost youth, severed fingers, irregular periods, and labour congealed in commodities for export. The future promised by communism has been erased by a seemingly eternal capitalist present. To dream again requires new acts of poetic and political imagination.
Andy Warhol, Hammer and Sickle, 1976.

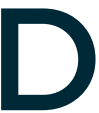

people need a future in order to live?

This essay begins from the premise that the loss of the promise of communism is also a loss of the horizon of future. Communism is not another discarded utopiaas Rancière $(2013,63)$ puts it, 'only a variant of this much older lie' that leads 'us to believe that something of what we waited for has come to pass'. Communism, to read Rancière (2012, 209) against himself, inaugurates 'the revelation of a different world and the initiation of a relationship between beings'. 
Communism does not promise a world without negativity, desire, or death, but a movement which abolishes the antagonism that consigns the majority of the world's population to a life of superfluity. The lucky ones, after all, are still appendages of capital accumulation. Under communism, there will be antagonisms, struggles, and politics, but they will be oriented toward a new lodestar of creation of different modes of social value rather than the inflammation and immiseration of profitdriven life. Communism is the promise that capitalism is not the terminal point in which the so-called 'end of history' will also be the annihilation of humanity.

The profound repercussions of what Ken Jowitt (1992) called the 'Leninist extinction' are still being felt today. This is not to glorify or demonise the complex historical records, legacies, and variations among actually existing communist regimes, which has been done elsewhere (Ghodsee 2017; Sorace et al. 2019), but salvage the form of the communist ideal from the rubble of the past. The receding of the 'communist horizon' (Dean 2018) gave us the permanent night of 'capitalist realism' (Fisher 2009) in which our imaginations and futures have been straight-jacketed by the forms of late capitalism and liberal democracy. Since the end of the Cold War, we dream only of apocalypse and not of a better world.

This essay proposes that the themes of migrant worker poetry in contemporary China bear the traces of the loss of the communist horizon. Chinese workers live under the paradoxical condition in which their emancipation was declared to have been achieved, which forecloses its possibility in the future. As a result, their lives are suspended in an eternal present of capital accumulation dressed up in socialist garb. In Alessandro Russo's formulation: 'If the main barrier against the political existence of works is the reference to a mummified working class enshrined in official discourse, nothing that is politically novel will be able to come into being unless there is an explicit, conscious effort to keep this fiction at bay' (Russo 2019, 35). Although I agree with Russo's point, fictions are not so easily displaced and brushed aside especially when they have the force of the Party-state apparatus behind them. The dual symbolic and political bind for the Chinese working class is that they live entombed in the representation of past emancipation in a world of capitalist exploitation (Franceschini and Sorace 2019).

Drawing from Iron Moon: An Anthology of Chinese Migrant Worker Poetry edited by Qin Xiaoyu and translated by Eleanor Goodman, and Selected Poems of Zhou Qizao translated by Song Deli, in this essay I argue that migrant worker poetry is a genre of mourning. As Claudia Pozzana puts it: 'In this era, when political visions of labour have become rarefied, the poetry of migrant workers can be read as a symptom of unmoored subjective existence' (Pozzana 2019, 193). What has unmoored the political and subjective existence of the working class is the loss of communism as a horizon. Without reducing migrant worker poetry to these categories, I have divided the rest of this essay into four experiences of loss: the loss of autonomy and experience of alienation; the exhaustion of vitality and wasted youth; the dismemberment of the body; and the loss of the future.

\section{Machinic Organs}

A key tenet of Marxism is that labour-power is a commodity that the worker needs to sell in order to live. The proletariat is the class 'who live only so long as they find work, and who find work only so long as their labour increases capital' (Marx and Engels 1848). A proletariat's life depends on the needs, fluctuations, and flows of capital, meaning most of us are 'allowed to live only insofar as the interest of the ruling class requires it' (Marx and Engels 1848). When a person is no longer profitable, the biopolitical state steps in to guarantee the minimum conditions for existence and prevent 
social disorder. The life and death stakes of the labour process for social reproduction is why Marx and Engels refer to work under capitalism as 'unfreedom.'

In his Economic \& Philosophic Manuscripts of 1844, Marx describes the selling of labour power for a wage as a form of 'self-estrangement' through which the worker's activity 'belongs to another; it is the loss of his self' (Marx 1844). Both the products and profits generated by the worker become someone else's property. The worker is emptied of energy, vitality, and youth in the process of producing wealth for the capitalist. Under capitalism, work is a 'labour of self-sacrifice, of mortification' (Marx 1844). In later works, Marx further explores how the individual is de-centred and stripped of autonomy in the labour process. In Capital Vol. 1, Marx argues that the worker is 'a living appendage of the machine' and 'mere fragment of his own body' (Marx 1867). In 'The Fragment on Machines' in The Grundrisse, Marx sketches how the worker's consciousness becomes a nodal point subsumed into 'the total process of the machinery itself', transforming 'living labour into a mere accessory of this machinery' through which the 'realisation process of capital' is achieved (Marx 1857-61). From the vantage point of the proletariat, Freud's famous statement-'Man has, as it were, become a kind of prosthetic God. When he puts on all his auxiliary organs, he is truly magnificent; but those organs have not grown on him and they still give him much trouble at times' (Freud 1989)-appears as a secular humanist dream in which man remains firmly at the centre of the universe, in the place formerly occupied by God, despite being subjected to the vicissitudes of the unconscious.

Migrant worker poetry gives poetic form to Marx's insights. Poet Chi Moshu (1980present) echoes Marx in his question: 'Can it be that we and our lives / are mere flesh accessories to the machines?' (Qin 2016, 142). Other poets call attention to how the labouring body submits but never quite adapts to the demands of production and rhythms of the assembly line. Chen Caifeng (1979-present) writes of being 'under fluorescent lights, frantically / seeking out any possible happiness' while feeling a 'panic implanted into the body' (Qin 2016, 96). The body is no longer the biological body but a blur of repetitive motion and localised pain, a nervous system calibrated to machinic pulsations (see Kindler's essay in the present issue). Zheng Xiaoqiong (1980present) describes how under the pressure of production, 'the cliff of the body collapses' and women's menstrual cycles are replaced by a 'life time of irregular periods' (Qin 2016, 124). The temporalities of production imprint themselves on the body (Pun 2005).

But machines are not necessarily cold, impersonal, and in opposition to the worker. Several poets express comradely affection and sympathy for machinery (Dean 2019, 65). People and machinery share similar fates: they wear out and are discarded when they no longer increase capital. Tie Gu (1969present) mourns an overworked tower crane that was forced 'with the boss's tacit consent / to shift heavy loads over and over until one day / it dropped its worn-out head into a news report' and in the next line adds 'my mother was a similar scene.' The poem ends with self-reflection of the poet's own 'squandered' life (Qin 2016, 49). Similarly, Tang Yihong (1970-present) eulogises a mixer that 'doesn't belong to itself' but to the 'construction site, the factory, the assembly line / to this gloomy life and reality / and even the rust on its body / will be beaten off with a heavy hammer'. The worker's alienation from his own body is mirrored in the poet's memory of the mixer's 'distorted face, and its inner / thundering and pain / don't belong to it either' (Qin 2016, 54).

\section{Wasted Youth}

Workers' youth is not their own. In 1957, Mao addressed Chinese students: 'The world is yours, as well as ours, but in the last analysis, it is yours. You young people, full of vigour and vitality, are in the bloom of life, like the 
sun at eight or nine in the morning. Our hope is placed on you. The world belongs to you, China's future belongs to you.' Contrast this optimism with these haunting lines from $\mathrm{Xu}$ Lizhi (1990-2014): 'I swallowed an iron moon / they called it a screw / I swallowed industrial wastewater and unemployment forms / bent over machines, our youth died young' (Qin 2016, 198). There is no sun in Xu Lizhi's poetry, only an 'iron moon' in the back of one's throat. The vitality of youth is spent in an effort to stay alive. Responding to a local journalist's question about the future, Xu Lizhi said: 'We all hope our lives will become better and better but most of us don't control our destiny' (Rauhala 2015). The poet's suicide is a monument to the absence of the future.

$\mathrm{Xu}$ Lizhi's comrade-poet-in-arms Zhou Qizao (1985-present) vividly depicts scenes of youth wasted on the production line: 'The youth on the / production line / Pale, weak / Quiet, stagnant and lonely / like weathered trees and / fallen leaves' (Zhou 2019, 32). The rosy faces of young workers etiolate like dead leaves. In the poet's account, youth and its possibilities are constrained to the increasingly 'narrow and narrow' space of the assembly line. A few stanzas down, the poet describes labour as a metabolic exchange of life for commodities and profits: 'Our brisk youth is bound / onto a line / Our young blood is used to / burn / to burn the passion of life.' Capital and blood are revealed as the dual substances of political economy sublimated in commodity fetishism.

The first stanza of Xie Xiangnan's (1974present) 'Orders of the Front Lines' shifts registers to the scatological:

My finest five years went into the input feeder of a machine

I watched those five youthful years come out of the machine's

Asshole-each formed into an elliptical plastic toy,

slippery, sometimes orange,

sometimes bright red and green eggshells. (I've heard they're shipped to America, shipped to Western Europe as Christmas toys, sold one after another

to blue-eyed children ....)

(Qin 2016, 79)

The anus of the machine shits out the poet's youth in the form of a plastic toy. Rather than the circulatory system of blood/ capital, Xie Xiangnan explores the digestive system of consumption/waste through which commodities are produced only to be discarded.

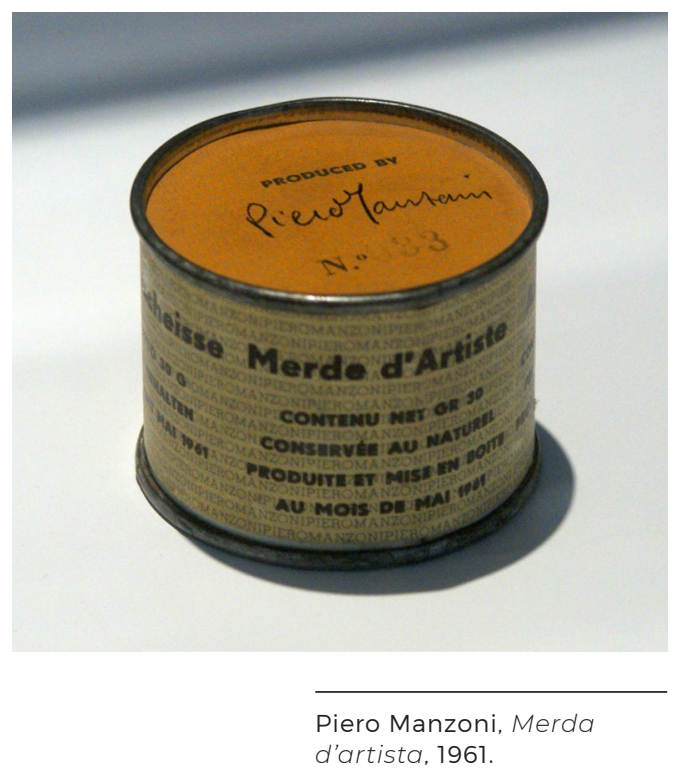

Zheng Xiaoqiong's poem 'Woman Worker: Youth Pinned to a Station' depicts how the worker and her labour congealed in the commodity are intertwined yet separated. The commodity's life-cycle begins with her own migration from 'an inland village / to a factory by the sea / all the way to a shelf in America'. Confined to the assembly line, she can only imagine the destiny of the commodity that carries a piece of her with it. But she cannot daydream for long because she too is a commodity subject to the disciplined temporality of production: 'She rubs her swollen red eyes / and sticks herself back / into the flow of products' (Qin 2016, 124). 


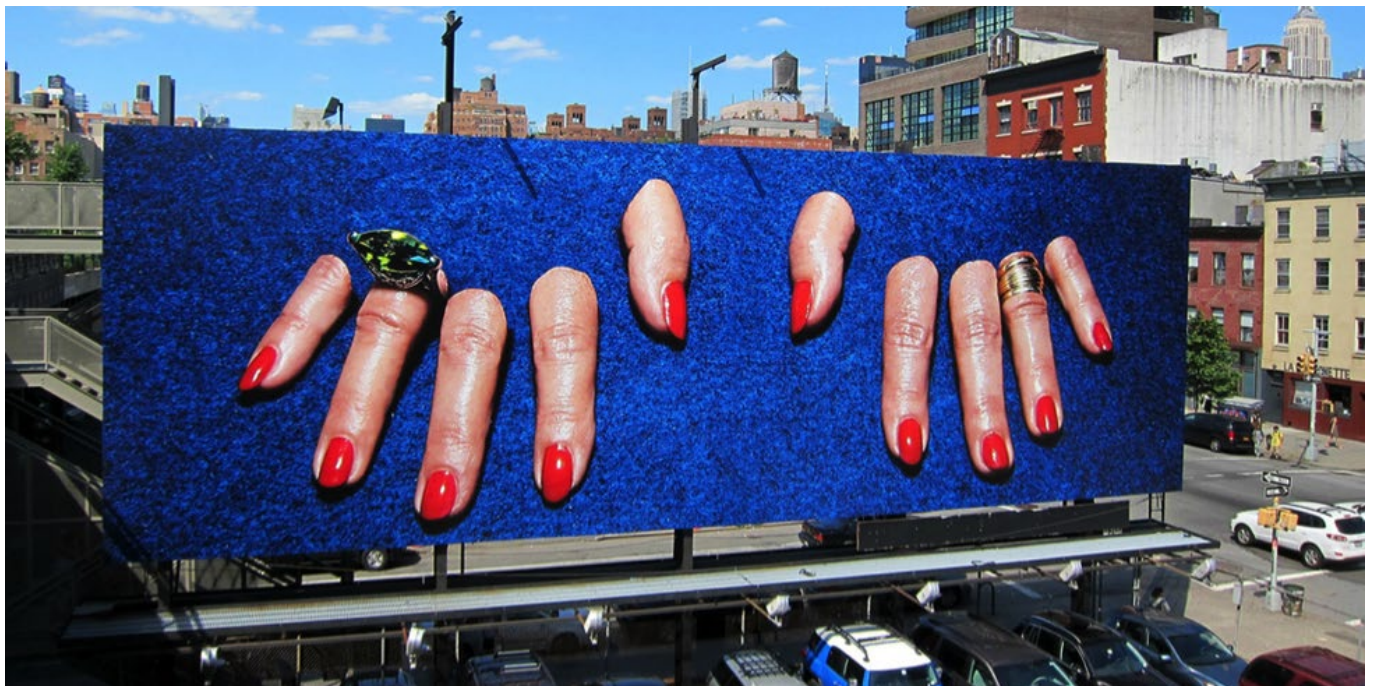

\section{'A Boy With a Severed Finger Examines His Hand on a Balcony'}

Working on construction sites, mines, or on assembly lines wears the body down as it valorises Capital. In the Marxist vernaculars of the twentieth century, language was attentive to the materiality of processes and bodies.

In Mandarin Chinese, the word for exploitation (剥削) conveys an image of layers of flesh being peeled, scraped, and pared down. Today, the visceral dimension of production is sublimated in the disembodied discourses of algorithms, statistics, and finance, which is why poetry is needed as a reminder of the sacrifices of the body on which the system rests.

In her poem 'Trial', Li Zhishui (1984-present) differentiates between what is quantifiable and unquantifiable in the production process:

In one minute, how much wood can be sawed

how many meters of cloth can be woven how many batteries can be assembled all of this can be calculated but how much sweat can flow in a minute how much dust and dark particulate can be taken into the lungs and organs how many people wander out of their villages

how many fingers are eaten by machines how many loves ones are separated by blood

that can't be calculated or figured the calculator and stop watch stare at me like I'm an accomplice.

(Qin 2016, 183)

Although the worker sells her labour-power for a wage determined by socially necessary labour time, what happens to the body exceeds calculation, which is to say, is beyond remuneration. How does one account for phantom digits?

Severed fingers have a ghostly presence in migrant worker poetry. The poet Li Shougang (1971-present) recalls the experience of losing four fingers on his left hand to a highpowered punch press with the lines: 'I had to 


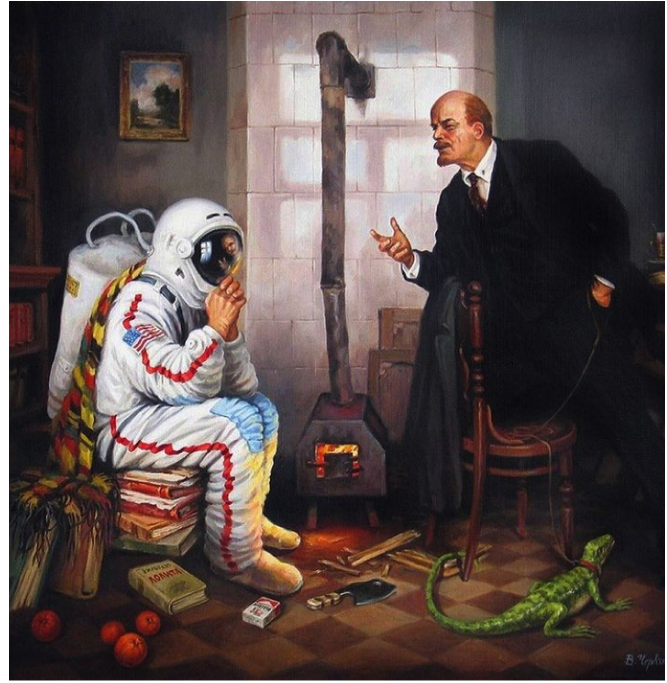

Vladimir Abat-Cherkasov, The Revolution Continues, undated.

face the pain / like I faced my damaged left hand / holding onto my heart' (Qin 2016, 70). Chi Moshu teaches how fingers cannot be reattached if the bones are crushed in his poem 'Severed Finger, No Sound of Crying' (Qin 2016, 156). Zheng Dong (1981-present) calls on his fellow workers to 'let our severed fingers make it to California / to collapse in front of the bosses' properties / let them entwine them like ferocious ghosts, generation after generation' (Qin 2016, 163). Zheng Xiaoqiang writes in and of the 'language of severed fingers' muted by the noise of 'the GDP's language' and 'language of official projects'. The poet gathers 'these sad languages' in order to 'speak them softly / in the roar of the machines' (Qin 2016, 122).

\section{Passport to the Future}

As inheritors of the revolution, the future of the Chinese working class is already behind them. Conversely, the factories of capitalism only offer a future in which 'the assembly line is our inescapable destiny' (Zhou 2019, 33). Chinese workers are trapped between the past glories of the Communist Party and the eternal recurrence of the capitalist present.

The Chinese migrant worker is buried under the bureaucracy of identity papers, residency permits, and employment forms. In his poem 'My Soviet Passport' (1929), Vladimir Mayakovsky (1893-1930) lashes out at such bureaucracy with the ferocious opening line 'I'd tear like a wolf at bureaucracy.' And yet, despite his hatred of bureaucracy, he prizes his red Soviet passport, which unlike the passports of other nation-states, promises access to a future of international proletarian solidarity.

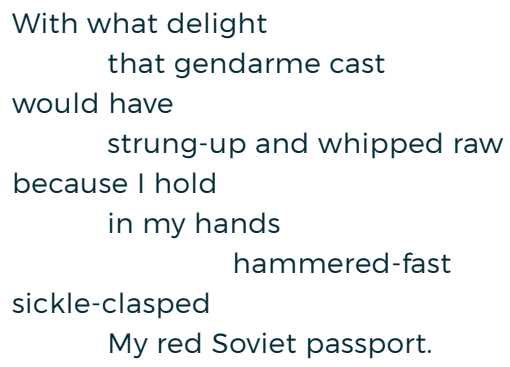

His Soviet passport is a 'bomb', 'rattlesnake huge and long / with at least / 20 fangs / poisontipped', and 'razor double-edged stropped' that strikes fear in the police while eliciting a glance of solidarity from a porter who notices its glinting red. Mayakovsky's evocation of a different world has fallen out of tune with the duet of slogans singing of 'the rejuvenation of the great Chinese nation' and 'Make America Great Again'. While the Chinese Communist Party competes with the United States for the execrable title of global hegemon, it is the voice of floating worker poets who keep open the promise of a future, even if they themselves no longer believe in it. 
This text is taken from Made in China Journal: Volume 5, Issue 1, 2020, edited by Ivan Franceschini, Nicholas Loubere and Christian Sorace, published 2020 by ANU Press, The Australian National University, Canberra, Australia.

doi.org/10.22459/MIC.05.01.2020.16 